\title{
EFFECT OF ACTINOMYCIN-D ON PROTEIN, RIBONUCLEIC ACID, AND ENZYME FORMATION \\ IN BACILLUS SUBTILIS
}

\author{
KIYOSHI KADOWAKI ${ }^{1}$, KAZUO YAMAGUCHI and BUNJI MARUO \\ Institute of Applied Microbiology, The University of Tokyo, \\ Bunkyo-ku, Tokyo, Japan \\ Received May 28, 1966
}

It has been widely accepted that actinomycin-D inhibits the synthesis of messenger RNA by binding with deoxyguanosine residue in DNA. The inhibition of RNA synthesis results in the inhibition of protein synthesis, and, accordingly, the inhibition of enzyme synthesis (1). A great deal of investigations on the inhibition of RNA synthesis and of protein synthesis caused by the addition of actinomycin-D have been reported. Only a few of them, however, recognized the differential effect of the antibiotic on the enzyme synthesis (2-7). In previous experiments (5), we compared the effect of actinomycin-D and 5-fluorouracil on amylase, alkaline phosphatase, and ribonuclease formations of Bacillus subtilis and observed following phenomena. While amylase and alkaline phosphatase formations were inhibited by the addition of $0.5 \mu \mathrm{g} / \mathrm{ml}$ of actinomycin-D, ribonuclease formation was not affected at the same concentration of the antibiotic. On the contrary, ribonuclease formation and alkaline phosphatase formation were sensitive to 5-fluorouracil, but amylase formation was quite resistant to this chemical.

These phenomena revealed that the action of actinomycin-D to protein synthesis is not homogeneous. In the present investigation, we compared in detail the effect of actinomycin-D on protein synthesis, ribonucleic acid synthesis, and enzyme formation.

\section{MATERIALS AND METHODS}

B. subtilis strain K (IAM-1523) was grown at $30^{\circ}$ for $18 \mathrm{hr}$ with shaking in the "BY" medium which contained bouillon $0.5 \%(\mathrm{w} / \mathrm{v})$, yeast extract $0.2 \%(\mathrm{w} / \mathrm{v})$, peptone $1 \%(\mathrm{w} / \mathrm{v})$, and $\mathrm{NaCl} 0.2 \%(\mathrm{w} / \mathrm{v})(\mathrm{pH} 7.3)$. The culture was then diluted 5-10 times with fresh BY medium, and the cells were incubated for about $3 \mathrm{hr}$ until the cells produced 40 units of amylase. The cells were then harvested by centrifugation and resuspended in the "lactate medium" which contained sodium lactate $0.3 \%$ (w/v), Bacto-peptone $1 \%$

1 Present Address: Research Laboratory of Choshi Soy Sauce Co., Choshi, Chiba. 
(w/v), $\mathrm{NaCl} 0.3 \%(\mathrm{w} / \mathrm{v}), \mathrm{MnCl}_{2} 0.02 \mathrm{mg} / \mathrm{liter}$, and tris $0.36 \%(\mathrm{w} / \mathrm{v})(\mathrm{pH} 6.8$ ). The cell concentration was adjusted to show an absorbancy of 0.600 at 550 $\mathrm{m} \mu$. After 1-hr incubation of the cell suspension in Monod's tube with shaking at $30^{\circ}$, actinomycin-D was added at various concentrations and the incubation was continued for further $2 \mathrm{hr}$.

Amylase and protease were assayed by the method of HaGiHARA (8), alkaline phosphatase by the method of WHITELEY and OISHI (9), and ribonuclease by the method described in the previous paper $(6)$.

The protein synthesis was measured by the incorporation of ${ }^{14} \mathrm{C}$-leucine into protein fraction. After $30 \mathrm{~min}$ of incubation in the presence of actinomycin-D, ${ }^{14} \mathrm{C}$-leucine $(0.2 \mu \mathrm{c} / \mathrm{ml}, 250 \mathrm{mc} / \mathrm{mmole})$ with $18 \mathrm{kinds}$ of amino acid $(0.01 \mu \mathrm{mole} / \mathrm{ml}$ each) was added to the culture medium and radioactivities incorporated into protein fraction during the following 30 min incubation were determined. The RNA synthesis was measured with the aid of ${ }^{14} \mathrm{C}$ adenine. ${ }^{14} \mathrm{C}$-Adenine was added $45 \mathrm{~min}$ after addition of actinomycin-D, and after $1 \mathrm{~min}$ of incubation, equal volume of cold $10 \%$ trichloroacetic acid was added. Radioactivities in RNA fraction were measured as described previously (5).

Actinomycin-D was the product of Merck, Sharp and Dohme Research Laboratory. ${ }^{14} \mathrm{C}$-Leucine and ${ }^{14} \mathrm{C}$-adenine were the products of the Radiochemical Centre, Amersham, England.

\section{RESULTS AND DISCUSSION}

Fig. 1 shows the effect of actinomycin-D at various concentrations on enzyme formation. As reported previously, formations of amylase, protease, and alkaline phosphatase were inhibited at lower concentration of actinomycin-D $(0.1 \mu \mathrm{g} / \mathrm{ml})$, while ribonuclease formation was inhibited at higher concentrations of the antibiotic (over $0.5 \mu \mathrm{g} / \mathrm{ml}$ ). In addition to these inhibitory effects, actinomycin-D also showed stimulatory effect on the formation of enzymes tested to a various degree at various concentrations. Formation of ribonuclease was stimulated up to $175 \%$ of the control at the concentration of $0.25 \mu \mathrm{g} / \mathrm{ml}$ of actinomycin-D, while those of other three enzymes were stimulated only slightly at the concentration of $0.05 \mu \mathrm{g} / \mathrm{ml}$ of the antibiotic. In such a stimulation, actinomycin-D showed a markedly different effect between ribonuclease and the other three enzymes. The fact that the formation of ribonuclease, which was more resistant to actinomycin-D, was enhanced to a higher level at a higher concentration of actinomycin-D would suggest the presence of an intimate relationship between inhibition and stimulation.

Fig. 2 shows the effect of actinomycin-D on the protein synthesis and RNA synthesis. The remarkable point was that the two curves were quite similar to each other, and no stimulation was observed at any concentration of actinomycin-D. 


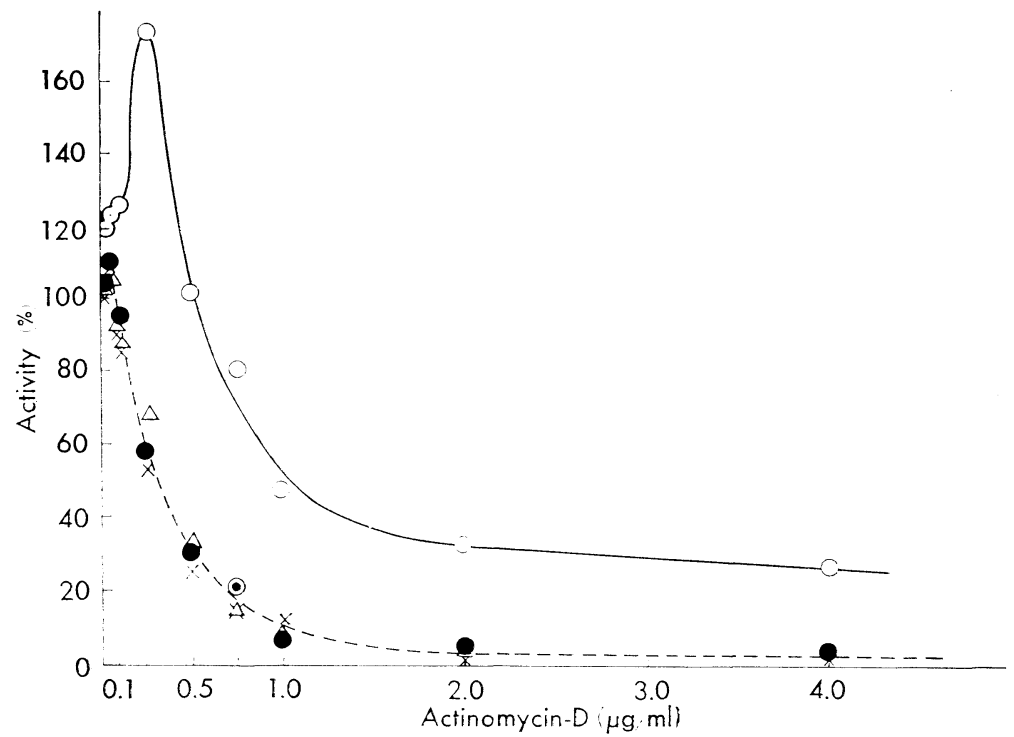

Fig. 1. Effects of various concentrations of actinomycin-D on enzyme formation.

After $1 \mathrm{hr}$ of incubation in lactate medium, various concentrations of actinomycin-D were added. Net increase of enzymes during the following $2 \mathrm{hr}$ was determined. Experimental details are given in the text.

- Amylase $\triangle$ APase $\times$ Protease $\bigcirc$ RNase

Similarity of the two inhibition curves agrees with the idea that the rate of protein synthesis as a whole is directly regulated by the synthesis of messenger RNA in bacterial cells.

The fact that no stimulation of protein synthesis or of RNA synthesis was observed at any concentration of actinomycin-D was quite contradictory to the effect of the same antibiotic on enzyme formation shown in Fig. 1. This contradiction would be explained either by assuming that such increase in enzyme activities is not related directry to the protein synthesis in this bacterium or by assuming that sensitivities to actinomycin-D of individual messenger RNA synthesis and accordingly of individual protein synthesis are different, but the RNA synthesis and protein synthesis measured by the incorporations of labeled compounds showed average values of individual ones. The former assumption, however, is inconsistent with the fact that the formation of these enzymes by this bacterium is immediately interrupted by addition of chloramphenicol or puromycin which is known to have a specific inhibitory effect on protein synthesis. 


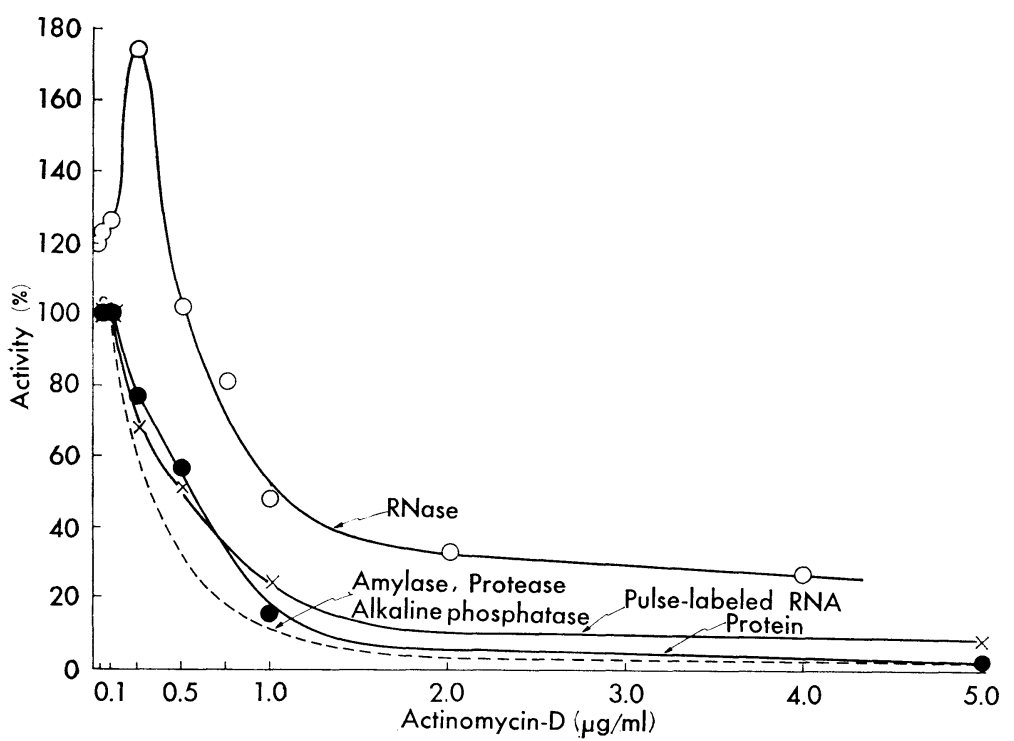

Fig. 2. Effect of various concentrations of actinomycin-D on synthesis of protein ( ) and pulse-labeled RNA $(X)$.

Syntheses of protein and pulse-labeled RNA were measured in terms of incorporations of ${ }^{14} \mathrm{C}$-leucine $(30 \mathrm{~min})$ and ${ }^{14} \mathrm{C}$-adenine (1 min), respectively. Experimental details are given in the text.

Stimulations of the synthesis of penicillinase (2), ribonuclease (3-4), and RNA viruses (10) by actinomycin-D have been reported. When some kinds of messenger RNA syntheses are inhibited more completely by the action of actinomycin-D, it would be very probable that the rest of the messenger RNA synthesized could be utilized more effectively for protein synthesis. When the inhibition and stimulation of enzyme formations are compared with those of RNA and protein syntheses, a large difference is observed only in the case of ribonuclease as shown in Fig. 2. These results agree well with the latter assumption mentioned above. More direct evidence may be obtained by studying the effect of actinomycin-D on the incorporation of labeled compounds into individual protein component, and if possible, individual messenger RNA.

\section{SUMMARY}

Effects of actinomycin-D on protein synthesis, RNA synthesis, and on formations of amylase, protease, alkaline phosphatase, and ribonuclease in Bacillus subtilis $\mathrm{K}$ were investigated.

The RNA synthesis and the protein synthesis were inhibited quite 
similarly by actinomycin-D of various concentrations. Inhibition of the formation of amylase, protease, and alkaline phosphatase was also similar, but ribonuclease formation was quite resistant and was stimulated markedly at a lower concentration of actinomycin-D.

The authors express their thanks to Drs. G. Denkewalter and H.B. Woodruff, Merck, Sharp and Dohme Research Laboratory, for their generous gift of the actinomycin-D. This work was supported in part by grants from the Ministry of Education of Japan and the Waksman Foundation of Japan.

\section{REFERENCES}

1) E. Reich and I. H. Goldberg: In Progress in Nucleic Acid Research and Molecular Biology, ed. by J.N. Davidson and Waldo E. Cohn, Academic Press, Inc., New York and London, Vol. 3 (1964), p. 184.

2) M.R. Pollock: Biochim. Biophys. Acta, 76, 80 (1963).

3) G. Coleman and W.H. Elliott: Nature, 202, 80 (1964).

4) G. Coleman and W.H. Elliott: Biochem. J., 95, 699 (1965).

5) K. Kadowaki, J. Hosoda and B. Maruo: Biochim. Biophys. Acta, 103, 311 (1965)

6) K. Kadowaki and B. Maruo: Biochim. Biophys. Acta, 119, 480 (1966).

7) K. Kadowaki and B. Maruo: J. Biochem. (Tokyo), in press.

8) B. Hagihara: Ann. Rept. Sci. Works, Fac. Sci., Osaka Univ., 2, 35 (1954).

9) H.R. Whiteley and M. Oishi: Biochem. Biophys. Res. Commun., 8, 342 (1962).

10) D.O. White and IAN M. Cheyne: Nature, 206, 813 (1965). 